\title{
Helyzetjelentés az európai klubfutballról (2017 - 2019)
}

\section{Situation Report of European Club Football (2017 - 2019)}

\author{
BÁCs B. A. ${ }^{1}$ \\ ${ }^{1}$ University of Debrecen, Faculty of Economics and Bussiness, Institute of Accounting and Finance \\ bacs.bence.andras@econ.unideb.hu
}

\begin{abstract}
Absztrakt. A sportágazat legprofesszionálisabban, és legprofitorientáltabban müködő szektora Európában a futball szektor. Az ágazat nemzetközi összefoglaló elemzései az utóbbi 20 év viszonylatában folyamatos bevétel emelkedést mutatnak. Az igazi fordulat az európai klubfutball jövedelmezőségét tekintve mégis 2017 volt, amikor is az európai top bajnokságokban játszó klubok aggregát eredménye nyereségként realizálódott. Mégis az utóbbi években komoly versenytársai akadnak a szektornak. Az esport követői bázisának és ehhez kapcsolódóan bevételeinek növekedési ütemével hívja fel magára a figyelmet. A fitnesz szektor pedig 2019-ben bevételei mértékében már meg is előzi a futball szektort. Jelen cikkben az európai futball 2017-tôl 2019-ig tartó időszakát kívánom áttekinteni, abból a szempontból, hogy a labdarúgó szektor jellemzőit feltárjam, megbizonyosodjak bevételtermelőképességéről, annak változásáról, bevétel szerkezetérôl és választ kapjak azokra a kérdésekre, hogy megtartja e domináns helyét az európai sportpiacon ez a sportág. Kutatási módszerem az UEFA és Deloitte által megjelentetett éves jelentések dokumentumelemzése, melyek segítségével 55 ország több mint 700 klubjának adatait vizsgálthatom. Összességében megállapítható, hogy a futball ipar Európában tartja a vezető helyét, azonban nem más sportágak veszélyeztetésétől kell tartania, hanem saját közönségbázisa stabilitására kell erőforrásokat allokálnia.
\end{abstract}

Abstract. The most professional and profit oriented sector of the sports industry is football. International summary analyzes of the sector show a steady increase in revenue over the last 20 years. Yet the real turning point in terms of the profitability of European club football was in 2017, when the aggregate result of the clubs playing in the top European leagues were realized as a profit. However in recent years, the sector has faced serious competitors. The esport industry draws attention to itself with the growth rate of the base of its' followers and related revenues. Also the fitness sector outperformed the football sector in 2019. In this article I reviewed european football between 2017 and 2019, in order to explore the characteristics of the football sector, to ascertain its revenue-generating capacity, its change in its revenue structure, and to answer the questions that if this sport will maintain its dominant position in the European sports market. My research method was document analisys of annual reports published by UEFA and Deloitte, which allowed me to examine data from more than 700 clubs in 55 countries. In overall it can be stated that the european football industry is maintaining it's position, but it should allocate resources to stabilize its follower base instead of fearing the endagerment by other sports.

Kulcsszavak: labdarúgás ágazata, klubfutball, bevételek, jövedelmezőség 
Keywords: football industry, club football, revenue, profitability

\section{Bevezetés}

A sportágazat legprofesszionálisabban, és legprofitorientáltabban működő szektora Európában a futball szektor. Az ágazat nemzetközi összefoglaló elemzései az utóbbi 20 év viszonylatában folyamatos bevétel emelkedést mutatnak. Az igazi fordulat az európai klubfutball jövedelmezőségét tekintve mégis 2017 volt, amikor is az európai top bajnokságokban játszó klubok aggregát eredménye nyereségként realizálódott. Már nemcsak a Big Five bajnokság, de összességében az európai klubfutball profitabilitása bizonyosodott be, köszönhetően az UEFA által 2012-ben bevezetett Financial Fair Play, azaz „Pénzügyi Fair Play" szabályrendszernek. A labdarugók játékjogának értékelése, illetve azoknak adás-vétele alapvetően meghatározza a futball vállalatok működését. A játékjogok piaci értékének növekedésével párhuzamosan a klubok bérköltségei is jelentős mértékben emelkedtek. A bérinfláció 2018-ban összesen 1,2 milliárd eurót tett ki, meghaladva a klubok 1,0 milliárd eurós teljes bevétel-növekedését. A munkaerővel kapcsolatos gazdasági trendek mellett, a bevételek összetételével kapcsolatban is megfigyelhető egy struktúra változási folyamat, amely során a televíziós közvetítési jogok bevétele, a mérkőzésnapi, a kereskedelmi, a szponzori és az UEFA bevételeket is jelentősen megelőzi növekedési ütemében. Ezek a jelenségek a labdarúgás gazdasági környezetének jelentős átalakulására irányítják a figyelmet, amellyel még a nagy, nemzetközi porondon sikeres kluboknak is kihívás szembe nézni.

A futball ipar sajátos gazdasági nehézségein felül érdemes a sportág versenytársaira is figyelmet szentelni. Az esport korunk egyik feltörekvő „sportága”, amelynek bevétel növekedési üteme ijesztő képet festhet a futball ipar számára, még akkor is, ha ezen bevételek reál értéke most még csak elenyésző részét érik el a futball bevételeinek. A szektor 2015-ben globális szinten csupán 325 millió dolláros bevétele, 2018-ra 900 millió dollárra növekedett, ami évente átlagosan közel 60\%-os (58,9\%) növekedést jelent. A bevételnövekedés mellett az esport közönségbázisa ugyanebben az időszakban (2015-2018) is hasonló mértékben növekedett 235 millióról, 395 millió követőre. A sportág gazdasági vezető szerepét az esporton kívül más sportok is veszélyeztetik, amelyeknél már nem csak prognosztizálható, hogy utolérik vagy megelőzik a futball szektort bevételtermelőképességben, de meg is haladják. Az európai fitnesz szektor bevétele például 2019-ben 28,2 milliárd eurós értékével - amely az észak-amerikai fitnesz szektorénál is magasabb - megelőzi a futballt, amely ugyanekkor „csak” 25,1 milliárd euró bevételt tudott produkálni.

Jelen cikkben az európai futball 2017-2019-ig tartó időszakát kívánom áttekinteni, abból a szempontból, hogy a labdarúgó szektor jellemzőit feltárjam, megbizonyosodjak bevételtermelőképességéről, annak változásáról, bevétel szerkezetéről és választ kapjak arra a kérdésre, hogy megtartja-e domináns helyét az európai sportpiacon ez a sportág.

\section{Szakirodalmi áttekintés}

A labdarúgó szektor működésének alapvetése az, hogy a sportbeli sikeresség gazdasági sikerességgel párosul [1-10]. A magas bevételt generáló klubok bevételeiket a jó sport teljesítmény biztosítására, például játékosállományukra fordíthatják, ami viszont lehetővé teszi számukra, hogy tovább növeljék bevételeiket a nézőszám, a közvetítések és a játékos eladások stb. révén [11-12]. 
Mára, ahogy gyarapszik a labdarúgás helyzetének átfogó elemzésével foglalkozó szakirodalom, úgy válik egyre részletgazdagabbá is a klubok teljesítménye mögött álló okok feltárása.

Az 1990-es évek vége óta egyre több elméleti és empirikus kutatás foglalkozik a futball ágazat kettős eredményességének vizsgálatával. Szymanski-Smith (1997) [13] az angol profi futballklubok 1974 és 1989 közötti pénzügyi teljesítménye alapján elméleti modellt dolgoztak ki, a kereslet és a termelés korlátainak figyelembe vételével. A modell a haszonkulcs és a bajnokság teljesítménye között lineáris összefüggést tár fel, valamint megállapítják, hogy a bevételek a bajnokságban elért teljesítménytől függnek. Szymanski-Kuypers (1999) [14] regressziós elemzéssel igazolja, hogy a bajnokságban elért helyezés meghatározza a klubok bevételeit. Garcia-del-Barrio-Szymanski (2009) [15] spanyol és angol profi futballklubok, 1994 és 2004 közötti maximalizáló viselkedését Szymanski és Smith (1997) [13] elméleti modelljének felhasználásával vizsgálják, és megállapítják, hogy mindkét liga esetében a klubokat inkább a sportbeli eredményesség vezérli, mint a profitmaximalizálás.

Dobson és Goddard (1998) [2] az előző eredményekkel ellentétben 77, 1946 és 1994 között folyamatosan működő klub vizsgálatakor fordított hatást állapít meg, azaz azt, hogy nem a sportbeli eredmény határozza meg a bevételeket, hanem a bevételek a sportbeli teljesítményt (Rohde-Beurer, 2016A). Buraimo et al. (2007) [16] hasonlóan Dobbson és Goddard-hoz arra az eredményre jut az angol profi liga vizsgálatakor, hogy a nagyobb bevételű csapatok, jobb bajnoki helyezéssel, vagy nyerési százalékkal rendelkeznek, mint a kisebb bevételűek.

Az európai labdarúgás egészét tekintve általánosan elfogadható megállapítás, miszerint a kutatók a kontinensen lévő klubokat „győzelem” maximalizálóknak, az angol klubokat pedig vagy profit- vagy győzelem maximalizálónak tartják [14].

A 2000-es években a klubok tulajdonosi viszonyainak vizsgálata erősödött fel, a magánbefektetők jelentős mértékű megjelenése miatt [17]. Először a sportbefektetők megjelenésével kialakult tulajdonosi háttér jellemzésével és az új tulajdonosok által alkalmazott irányítási modellekkel foglalkoztak a szakírók. Ezután a hangsúly a klubok finanszírozási kereteinek változására tevődött át, mivel az új tulajdonosokat aktív játékos piaci tevékenység jellemezte, az átigazolási díjak és a játékos fizetések nőttek, így a klubok egyre nagyobb forrásokat igényeltek versenykésességük megőrzéséhez [18]. A gazdasági ösztönzők megváltoztak, a csapatok egyre inkább „kiadási erejük” alapján versenyeztek [19].

Franck (2010) [20] a magántulajdonban lévő labdarúgó klubok esetében igazolja, hogy számukra a tőkebevonás és a klubirányítás átalakítása kiemelkedő jelentőségű volt. Rohde és Breuer (2016) [21] az angol Premier League vizsgálata alapján megerősíti, hogy a magántulajdonosok ösztönzőleg hatnak a tőkebefektetésre. A külföldi többségi befektetők vizsgálatakor továbbá feltárták még, hogy azok inkább profitmaximalizálók, mintsem sporteredmény maximalizálók lennének [17].

A labdarúgás irányító hatóságai a magántőke befektetések negatív hatásait érzékelve, szabályozási intézkedésekkel kívánták azokat ellensúlyozni, például az UEFA bevezette a Financial Fair Play (FFP) szabályozást [20; 22], illetve Németországban alkalmazták az „50 + 1” szabályt.

Madden (2015) [23] klubtulajdonosok célkitűzéseit modellezve az UEFA FFP szabályozásának a bajnokságra gyakorolt hatását is elemzi. Eszerint a tulajdonosok tőkeinjekciójával szemben az FFP rendszer gyenge eszköznek bizonyult. 
Wilson et al. (2013) [17] a klubtulajdonlási viszonyok vizsgálatakor azt találta, hogy a tőzsdére bevitt klubok jobban teljesítettek a bajnokságban, mint a hazai tulajdonú klubok, illetve nagyobb valószínűséggel feleltek meg a FFP elő́rásoknak. Ezzel ellentétben Sakinc et al., (2017) [24] elemzésében nem talált statisztikailag szignifikáns kapcsolatot 22, különböző európai tőzsdéken jegyzett futballklub esetében a sportteljesítmény és a pénzügyi teljesítmény között.

Barajas-Rodrigez (2014) [25] az európai, különösen a spanyol futball pénzügyi nehézségeiről írt. A klubok 2007 és 2011 közötti időszakát vizsgálva bizonyítja a spanyol klubok rossz anyagi helyzetét, amelyen szerinte a részvény kibocsátás, a tagok jelentős hozzájárulása, a bérek, fizetések csökkentése segíthetne.

Grossmann (2015) [26] a tőkeinjekciók kapcsán már a futballklubok túlélésért folytatott gazdasági versenyről ír.

Az elmúlt két évtizedben a futball klubok forgalma folyamatosan és jelentősen megnőtt. Ez a jelenség is az elemzők vizsgálati fókuszába került. A Deloitte Tanácsadó szevezet évente elkészíti jelentését az úgy nevezett „labdarúgás Pénz Ligáját” a legnagyobb forgalomú európai klubokról, illetve az UEFA is közzéteszi az ágazat nemzetközi összefoglaló elemzéseit évről-évre. Az európai futball „elit” egy körülbelül 30 klubból álló kis csoport, amely többnyire Angliában, Olaszországban, Spanyolországban, Németországban és Franciaországban, a Big Five bajnokságban szerepel. Ezek a klubok vezetik a Deloitte Football Money League rangsorát az európai legjobb labdarúgó klubok között a bevételek alapján. Ők nyerik meg a nemzeti és az európai futballversenyek túlnyomó részét, és ők szerepelnek a FIFA világeseményeinek nagy részén is [22]. A vezető klubok pénzügyi helyzetének elemzése mellett több európai összegző [28] és több nemzeti keretekben vizsgálódó elemzés született [29-32].

Az utóbbi 20 év viszonylatában a labdarúgó ágazat európai összesített adatai szerint folyamatos a bevétel emelkedés, ám az ágazat összeredménye veszteséget mutatott. Ezért az európai labdarúgás esetében történelmi fordulópontként tarthatjuk nyilván 2017-et, mivel ez volt az első olyan pénzügyi év, amikor az európai bajnokságokban játszó klubok aggregát eredménye nyereségként realizálódott. Ekkor már nemcsak a Big Five bajnokság, de összességében az európai klubfutball profitabilitása bizonyosodott be.

\section{Anyag és módszer}

Vizsgálati módszerként a dokumentumelemzést választottam. Az „UEFA Club Financial Report"-jait, a "Deloitte Football Money League” jelentéseit kívánom felhasználni az adatok kinyerésére. Ezek a források 55 ország, több mint 700 klubjának összegző adatai, a futball elitjéhez tartozó top 20 klub részletező adatait biztosítják számomkra.

Vizsgálati időszaknak a 2017-2019-ig tartó időszakot választottam ki. Egyrészt azért mert 2017-ben volt az európai klubfutball első összességében nyereséges éve, másrészt ez a COVID19 járványt megelőző, még teljes üzleti működéssel jellemezhető időszak. 


\section{Eredmények}

Az európai klubok tulajdonosi szerkezete változatos képet mutat, különböző arányokban a két „véglet” között: a tiszta magántulajdonban lévő gazdasági társasági forma, és a tagsági tulajdonú egyesületi forma között mozog. A vizsgált időszakban 11 európai bajnokságban kizárólag magántulajdonban lévő gazdasági társaságok működtették a csapatokat. A gazdasági társasági formák közül a leggyakrabban a korlátolt felelősségű társasági formát alkalmazták. 2017-ben 14, 2018-ban 11 bajnokságban kizárólag egyesületi formában működő klubok versenyeztek. A többi bajnokságban ez a két tulajdonosi forma együtt jelent meg, illetve 13 bajnokságban ezen két típus mellett az állami és az önkormányzati tulajdonrész is képviseltette magát. Összességében a klubok 67\%-a volt magán, 33\%-a valamilyen (egyesületi, állami, önkormányzati) közösségi tulajdonban. 67 klub rendelkezett külföldi tulajdonossal, ami azt jelenti, hogy az UEFA tagországainak felében legalább egy külföldi klubtulajdonos volt. A klubok 13\%-nál tulajdonos váltás is történt 2018/19-re.

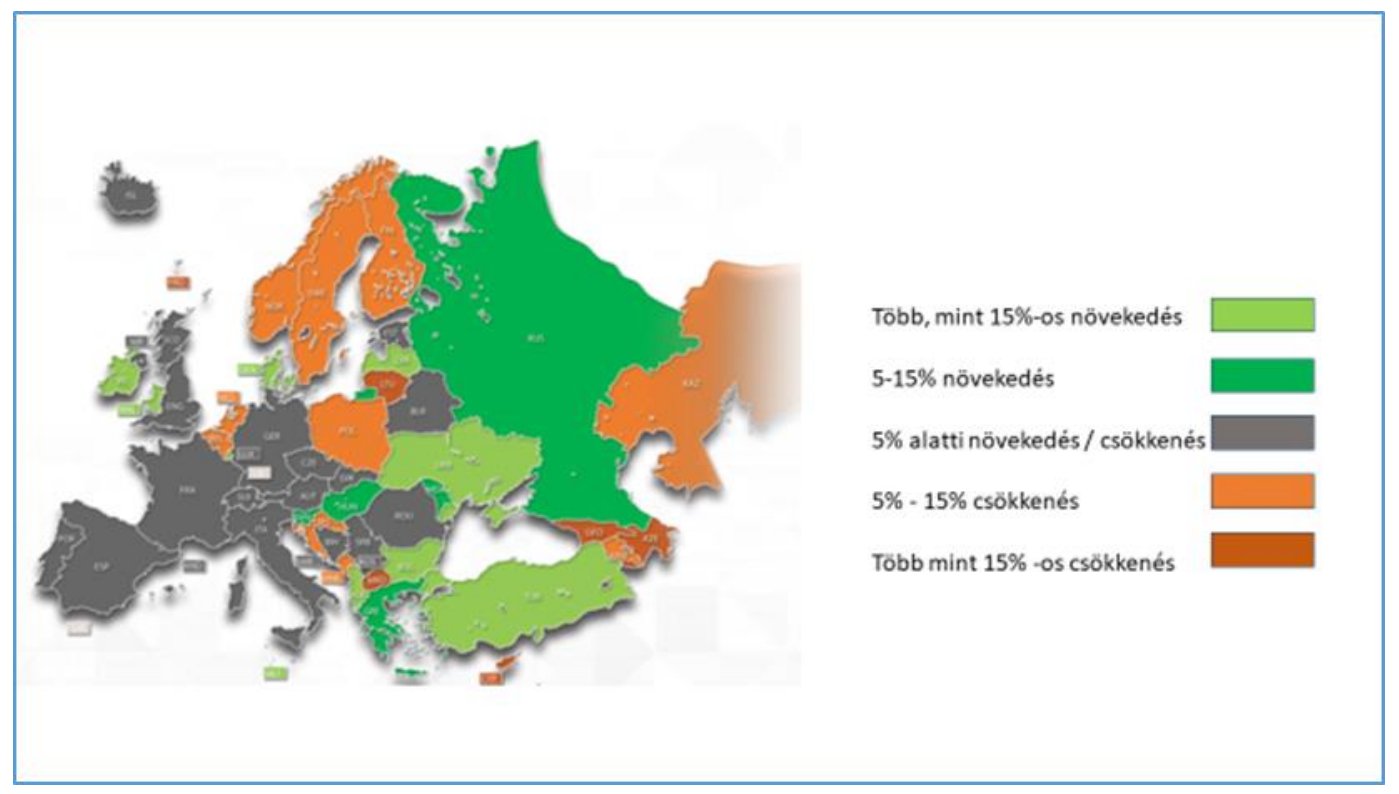

1. ábra Helyszíni nézettség alakulása az európai klubfutballban 2018-ben

Forrás: UEFA alapján saját szerkesztés

A labdarúgás nézettségi adatai arról árulkodnak, hogy növekszik az érdeklődés a sportág iránt, biztos fogyasztói piaca van. A klubok tekintetében átlagosan az első vizsgált bajnoki idényben az előzőhöz képest 6,4\%-os, a másodikban 2\%-os növekedés tapasztalható. Az átlagos klub nézőszám 8,8 ezer főről 9 ezerre nőtt. Összesítve az európai klubok látogatottságát megállapítható, hogy a 2017/18-as bajnokság 100 millió fős nézettségét 5 millió fővel nőtte túl a 2018/19-es. A növekedés mögött bajnokság tekintetében az orosz, a török és a görög bajnokságok látogatottságának növekedése áll, míg klub sznten az első vizsgált bajnoki szezonban a Manchester United FC, a Borussia Dortmund és a Tottenham Hotspur FC, a másodikban az FC Barcelona, a Manchester United FC, és a Tottenham Hotspur FC aggregát nézőszámai voltak a legmagasabbak.

A klub futball iránti érdeklődés stabilitását bizonyítja, hogy a 2018/19-es idényben még azokban a bajnokságokban sem volt komoly visszaesés, ahol a bajnoki mérkőzések a világbajnokság idején is 
zajlottak. Ez összességében egy stabil fogyasztói piacot mutat, hiszen a klubok egy harmada 5\%-nál kisebb változást tapasztalt a nézőszámok tekintetében a vizsgált időszak végére.

Az európai klubfutball bevételei 20 éve folyamatosan emelkednek, 2016-ban 18,466; 2017-ben 20,102; 2018-ban 21,083 milliárd; 2019-ben 25,1 milliárd Eurót értek el. Ez az utolsó időszak viszonylatában közel 5\%-os növekedést jelent. Ám ez egy összesített eredmény, amely mögött jelentős aránytalanságok rejlenek. A Big 5, azaz az angol, a francia, a német, a spanyol és az olasz bajnokság termeli a bevételek 74\%-át az első két, és 75\%-át a harmadik évben. Az angol bajnokság 20 klubja több bevételt termel, mint a Big 5-on kívüli további 40 tagország klubjai.

\begin{tabular}{|c|c|c|c|c|c|c|c|}
\hline Ország & $\begin{array}{l}\text { Közvetí- } \\
\text { tési jog }\end{array}$ & UEFA & Jegy & $\begin{array}{l}\text { Szponz./ } \\
\text { Keresk. }\end{array}$ & Egyég & $\begin{array}{l}\text { Transzf. } \\
\text { Össz.ből }\end{array}$ & $\begin{array}{l}\text { Összes } \\
\text { bevétel }\end{array}$ \\
\hline \multicolumn{8}{|l|}{ BIG 5} \\
\hline ENG & $53 \%$ & $7 \%$ & $13 \%$ & $26 \%$ & $1 \%$ & $23 \%$ & $5439 \mathrm{~m}$ \\
\hline GER & $34 \%$ & $7 \%$ & $16 \%$ & $38 \%$ & $5 \%$ & $20 \%$ & $3156 \mathrm{~m}$ \\
\hline ESP & $42 \%$ & $8 \%$ & $18 \%$ & $27 \%$ & $5 \%$ & $25 \%$ & $3145 \mathrm{~m}$ \\
\hline ITA & $47 \%$ & $11 \%$ & $12 \%$ & $25 \%$ & $6 \%$ & $40 \%$ & $2307 \mathrm{~m}$ \\
\hline FRA & $37 \%$ & $11 \%$ & $16 \%$ & $24 \%$ & $13 \%$ & $54 \%$ & $1694 \mathrm{~m}$ \\
\hline \multicolumn{8}{|l|}{ V 4} \\
\hline POL & $25 \%$ & $5 \%$ & $14 \%$ & $41 \%$ & $14 \%$ & $28 \%$ & $125 \mathrm{~m}$ \\
\hline CZE & $7 \%$ & $24 \%$ & $10 \%$ & $47 \%$ & $12 \%$ & $48 \%$ & $81 \mathrm{~m}$ \\
\hline SLO & $2 \%$ & $20 \%$ & $9 \%$ & $58 \%$ & $12 \%$ & $41 \%$ & $43 \mathrm{~m}$ \\
\hline
\end{tabular}

1. táblázat A Big 5 és a V4 országok bajnokságainak bevétel szerkezet 2018-ban (€)

Forrás: UEFA alapján saját szerkesztés

A bevételek növekedési üteme eltérő, 2017-ben 43, 2018-ban 38 tagország bajnoksága produkált magasabb bevételeket. 15 országban volt számottevő, több mint $15 \%$-os, további 14 országban 5\% és 15\% közötti, 9 országban pedig 5\% alatti növekedés. Klub szinten a Real Madrid FC, az FC Barcelona és a Manchester United FC bonyolítja le a legnagyobb forgalmat a vizsgált időszakban.

A bevétel szerkezetet tekintve 2018-ban a közvetítési jogdíjak 37\%-ot, a szponzoráció 23\%-ot, a jegybevételek 15\%-ot, az UEFA díjak 10\%-ot, a kereskedelmi bevételek 8\%-ot, az egyéb bevételek 7\%ot tettek ki az európai klubfutball aggregát bevételéből. 
A közvetítési bevételek 2017-es, a valaha volt legnagyobb arányú növekedését követően, 2018-ban tovább nőttek 380 millió Euróval, ami 5\% -os éves szintű növekedést jelent. Ennek hátterében leginkább (70\%-ban) a Bundesliga közvetítési jogdíjának megújulása állt.

A jegybevételek 2017-ről, 2018-ra 8\%-os, az elmúlt évtized legmagasabb értékű növekedését érték el. Az UEFA-tól érkező bevételek változatlan arányúak maradtak, csak 2018-ban ebből az angol klubok többet, a spanyol klubok kevesebbet profitáltak.

A legnagyobb bevételtermelő képességgel rendelkező Big 5 bajnokság bevétel szerkezete úgy alakult, hogy bevételeik legnagyobb részét a közvetítési jogok tették ki, amit a szponzori, majd az UEFA és végül a jegybevételek követték.

A V4 bajnokságainak bevételszerkezetét is megvizsgáltam. A Big 5-tól eltérően itt a szponzori bevételek a legnagyobbak, amit Csehország és Lengyelország esetében az UEFA, Szlovákia esetében az egyéb bevételek követnek. A harmadik helyen Lengyelország esetében a közvetítési bevételek, a másik két ország esetében 9 és 10\%-kal a jegybevételek álltak.

Az európai klubfutball két nyereséges évét 2017-ben 1,417 milliárd eurós, 2018-ban kevesebb, 697 millió eurós profit jellemezte. E mögött 2017-ben az európai klubok 61\%-nak, 2018-ban 55\%-nak nyereséges múködése állt. Azonban megint csak megfigyelhető a „nagyok” hatása, hiszen a 2018-as nyereségből az angol klubok 382 millió eurót hoztak. Klub szinten az elmúlt tíz év mindegyikében csak három klub volt, amelyik mind a tíz évben nettó nyereséget hozott, az Arsenal FC, az FC Bayern München és a Real Madrid CF.

A labdarúgás tekintetében a ráfordítások legjelentősebb tényezője a bér költség. 2012 előtt a bérek minden évben gyorsabban növekedtek, mint a bevételek. Ám 2012 óta már négy évben fordult elő, hogy az európai klubbevételek gyorsabban nőttek, mint a játékos bérek. Ez a költségkontroll a klubok pénzügyi helyzetének javulását idézte elő. A magas bérinfláció azonban 2018-ban visszatért, a bevételek 4,9\% -os növekedését meghaladva elérte a 9,4\%-t 2018-ban, ami az elmúlt évtized legmagasabb aranya. A béremelés euróban kifejezve 1,2 milliárd euró volt (a bevételek összesített növekedését pedig 1,0 milliárd euró).

A labdarúgó klubok múködésének egyik legfontosabb mutatója a bérek és a bevételek aránya. 2018-ban ez a mutató tükrözve a bérinflációt, 63,9\% -ra emelkedett, pedig 2017-ben ez a mutató tízéves mélyponton, 61,3\% -on állt. Ugyanakkor a 2018-as arány továbbra is alacsonyabb, mint amilyen a pénzügyi fair play (FFP) szabályozás bevezetése előtt volt. 


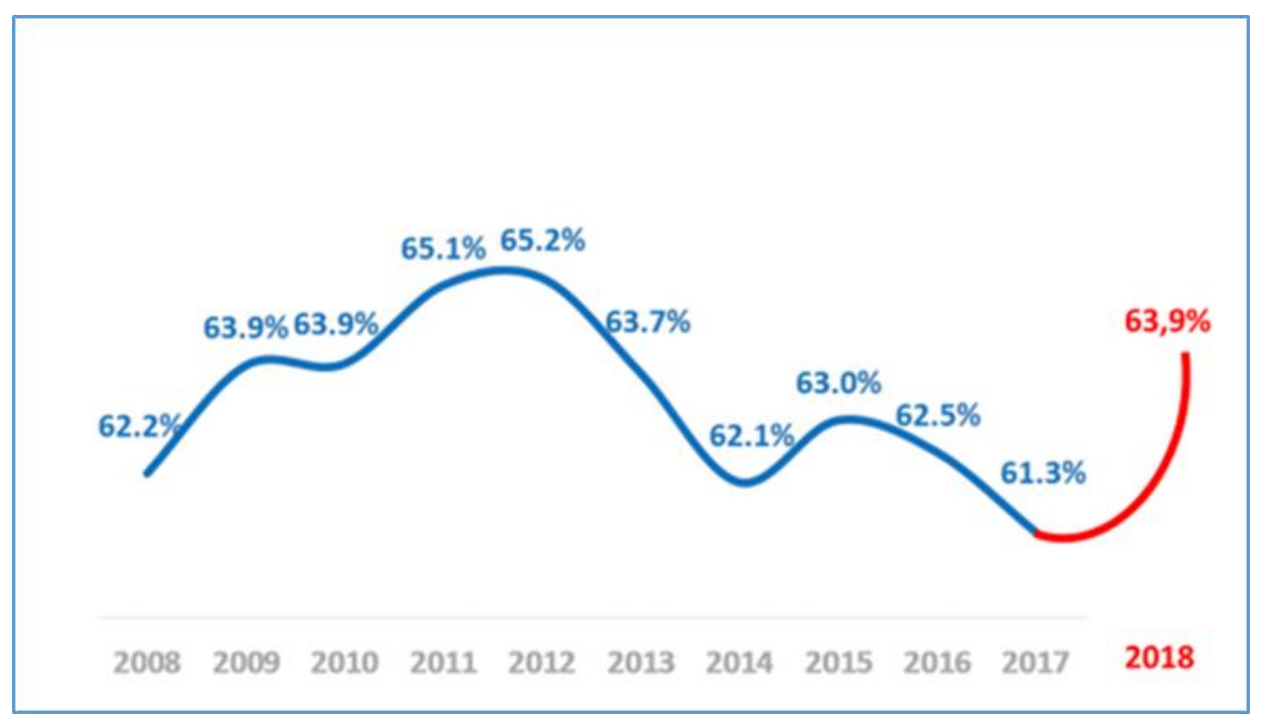

3. . ábra: Bér-árbevétel arány az európai klubfutballban 2008-2018

Forrás: UEFA alapján saját szerkesztés

\section{Következtetések}

A Az európai klubfutballt meghatározza tulajdonosi szerkezete, amelyben egyre dominánsabbá válik a magántulajdon, amin belül a külföldi befektetők jelentősége folyamatosan emelkedik. Mivel a magántulajdon szabadon adhatóvá és vehetővé teszi a klubokat ez a sportág fejlődését tekintve meghatározó tényezővé válhat, hiszen ez a tulajdonosi szerkezet együtt jár az Európán kívülről igazolt magas fizetésekkel rendelkező játékosok szerződtetésével is. Ez a jelenség azt okozhatja, hogy a legjobb csapatok elszakadnak az átlagos, vagy kisebb a financiális lehetőségekkel rendelkező csapatoktól, mind üzleti, mind sporteredményesség tekintetében. Ezt a jelenséget némileg kordában tartja az UEFA FFP szabályozása.

A futball szektor uralkodó helyzetét tekintve megnyugtató, hogy a vizsgált időszakban igazolható a bevételek folyamatos növekedése, ami évente átlagosan 12,43\%-ot jelent. A bevétel szerkezetét tekintve meghatározóak a közvetítési jogok, azonban ha a tagországokra részletesen kitérünk, akkor igazolható, hogy ez az eredmény a Big Five ligának köszönhető. Ez az európai futball piac sajátosságára világít rá, miszerint a nagyok jellegzetességei az aggregát összeurópai értékeket átírják. Kisebb tagországok kisebb bajnokságaiban a szponzori bevételek és támogatások aránya magasabb, ami arra utal, hogy ezek az országok minden eszközzel - akár nem is üzletiekkel - igyekeznek lépést tartani a nagy európai klubokkal. Az árbevétel bér arány mutató, ami a labdarúgás legjellegzetesebb mutatója, hosszú idő óta javuló tendenciát mutat, de figyelmeztető jel lehet, hogy e tekintetben 2019ben visszaesés történt, illetve a Covid vírus hatására a klubok bevételei nagy mértékben csökkennek a következő beszámolási időszakban. 
Összességében a többi sportág nem taszította még le „trónjáról” a futballt. Talán nem is a többi sportágtól kell tartania a labdarúgásnak, hanem a sportág gazdasági kockázatának csökkentésére saját nézői bázisának hosszútávú biztosítására kell koncentrálni, hiszen végső soron a nézők befolyásolják alapvetően a labdarúgás további (szponzori, közvetítési, merchandising stb.) bevételeit is.

\section{Összefoglalás}

A sportgazdaságban bekövetkező tendenciák, mint egyes sportágak (pl. az esport) iránti növekvő érdeklődés, illetve más sportágak (pl. a fitnesz szektor) növekvő bevételtermelése felveti a kérdést, hogy a futball tartja e vezető szerepét a sportpiacon, különösen az európai piacon.

Jelen cikkben az európai futball 2017-től 2019-ig tartó időszakát vizsgáltam, abból a szempontból, hogy a labdarúgó szektor jellemzőit feltárjam, megbizonyosodjak bevételtermelőképességéről, annak változásáról, bevétel szerkezetéről és választ kapjak azokra a kérdésekre, hogy megtartja-e domináns helyét az európai sportpiacon ez a sportág.

Összességében megállapítható, hogy a futball ipar Európában tartja a helyét, azonban a sportágban rejlő gazdasági kockázat csökkentése érdekében közönségbázisa stabilizálására, fejlesztésére kell fókuszálnia. Ez úgy tünik nem is lesz olyan egyszerü feladat, hiszen Florentino Perez - a Real Madrid FC elnöke, a tervezett Superliga elnöke - a Superliga létjogosultsága mellett érvelve olyan általuk készített statisztikákra hivatkozott, melyek szerint a 16-24 éveseket már sokkal kevésbé érdekli a futball, mint az idősebb generációkat.

\section{Hivatkozások}

[1] Szymanski, S. (1998). Why is Manchester United so successful?Business Strategy Review,9(4), 4754.

[2] Dobson S.M., Goddard A. (1998): Performance and revenue in professional league football: Evidence from Granger causality tests. Appl. Econ. 30 (1998): 1641-1651.

[3] Haas, D. J. (2003). Productive efficiency of English football teams-A data envelopment analysis approach. Managerial and Decision Economics,24(5), 403-410.

[4] Haas, D. J., Kocher, M. G., Sutter, M. (2004): Measuring efficiency of German football teams by dataenvelopment analysis. Central European Journal of Operations Research,12(3), 251-268.

[5] Gerrard, B. (2005): A resource-utilization model of organizational efficiency in professional sports team. Journal of Sport Management,19(2), 143-169.

[6] Barros, C. P., Leach, S. (2006): Performance evaluation of the English premier football league with dataenvelopment analysis. Applied Economics,38(12), 1149-1458. 
[7] Pinnuck, M., Potter, B. (2006): Impact of on-field football success on the off-field financial performance ofAFL football clubs. Accounting and Finance,46(3), 499-517.

[8] Guzmán, I., Morrow, S. (2007): Measuring efficiency and productivity in professional football teams:Evidence from the English Premier League.Central European Journal of Operations Research,15(4), 309-328.

[9] Ribeiro, A. S., Lima, F. (2012): Portuguese football league efficiency and players wages. Applied EconomicsLetters,19(6), 599-602.

[10] Kounetas,K. (2014):Greek football clubs' efficiency before and after Euro2004 Victory: Abootstrap approach.Central European Journal of Operations Research,22(4), 623-645.

[11] Lago U., Baroncelli A., Szymanski S. (2004): (a cura di), Il business del calcio, successi sportivi e rovesci finanziari, Egea, Milano, 2004. RIVISTA DI DIRITTO ED ECONOMIA DELLO SPORT Vol. II, Fasc. 2, 2006

[12] Galariotis E.,-Germain C.,'Zopounidis C. (2018): A combined methodology for the concurrent evaluationof the business, financial and sports performanceof football clubs: the case of France. ANALYTICAL MODELS FOR FINANCIAL MODELING AND RISK MANAGEMENT. Ann Oper Res (2018) 266: 589-612.

[13] Szymanski S., Smith R.(1997): The English Football Industry: Profit, performance and industrial structure. Int. Rev. Appl. Econ. 11 (1997): 135-153.

[14] Szymanski S., Kuypers T. (1999): Winners \& Losers-The Business Strategy of Football. London, UK: Penguin Books, 1999.

[15] Garcia-del-Barrio P., Szymanski S. (2009): Goal! Profit Maximization versus Win Maximization in Soccer. Rev. Ind. Organ. 34 (2009): 45-68.

[16] Buraimo B., Forrest D., Simmons, R. (2007): Freedom of entry, market size, and competitiveoutcome: Evidence from English Soccer. Southern Economic Journal,74(1), 204-213.

[17] Wilson R., Plumley D., Ramchandani G. (2013): The relationship between ownership structure and club performance in the English Premier League. Sport Bus. Manag. Int. J. 3 (2013): 19-36.

[18] Baroncelli A., Lago U. (2006): Italian Football. J. Sports Econ. 7 (2006): 13-28.

[19] Dietl H. M., Franck E. (2006): Warum Investitionswettläufe und wachsende Erlösasymmetrien das Geschäftsmodell des europäischen Profifußballs zunehmend belasten. Zeitschrift Führung + Organisation 6 (2006): 333-337.

[20] Franck E. (2010): Private Firm, Public Corporation or Member's Association Governance Structures in European Football. Int. J. Sport Finance 5 (2010): 108-127.

[21] Rohde M., Breuer C. (2016): Europe's Elite Football: Financial Growth, Sporting Success, Transfer Investment, and Private Majority Investors. Int. J. Financial Stud. 2016, 4(2), 12.

[22] Sass M. (2016): Glory Hunters, Sugar Daddies, and Long-Term Competitive Balance under UEFA Financial Fair Play. J. Sports Econ. 17 (2016): 148-158. [Google Scholar] [CrossRef] 
[23] Madden P. (2015): Welfare economics of "financial fair play"in a sports league with benefactorowners. Journal of Sports Economics,16(2), 159-184.

[24] Sakınç İ., Açıkalın S., Soygüden A. (2017). Evaluation of the relationship between financial performance and sport success in European football. Journal of Physical Education and Sport, 17, 16-22.

[25] Barajas, A., Rodriguez, P. (2014): Spanish football in need of financial therapy: Cut expenses andinject capital. International Journal of Sport Finance,9(1), 73-90.

[26] Grossmann M. (2015): “Evolutionarily Stable Strategies in Sports Contests.” J. Sports Econ. 16 (2015): 108-121.

[27] Dimitropoulos P. E., Tsagkanos, A. (2012): Financial performance and corporate governance inthe European football industry. International Journal of Sport Finance,7(4), 280-308.

[28] Ecer F., Boyukaslan A. (2014): Measuring Performances of Football Clubs Using Financial Ratios: The Gray Relational Analysis Approach. American Journal of Economics2014, 4(1): 62-71.

[29] Dimitropoulos P. (2010): The Financial Performance ofthe Greek Football Clubs. Sport Management International Journal, 6, pp. 5-28.

[30] András K. (2003): Üzleti elemek a sportban, a labdarúgás példáján. PhD értekezés. Corvinus Egyetem, Budapest

[31] Bácsné Bába É., Bács, B. A., Bács, Z. (2018): Hazai professzionális labdarúgó klubok iparági elemzése - A magyar labdarúgás Pénz Ligája 2014-2016. INTERNATIONAL JOURNAL OF ENGINEERING AND MANAGEMENT SCIENCES / MÜSZAKI ÉS MENEDZSMENT TUDOMÁNYI KÖZLEMÉNYEK (2018) 3 : 5 pp. 284-296. , 13 p.

[32] Muszbek M. (2011): Sportgazdasági nagyító 2011. https://slideplayer.hu/slide/2051267/ Letöltve 2021. 03.10. 